\title{
Late Socialism as a Narrative Problem: Christoph Hein and the Limits of the Novella
}

\author{
(Published in Geman Studies Review 38.1, 2015)
}

Christoph Hein's Der fremde Freund, published in the GDR in 1982, counts as a paradigmatic postwar German novella. While the text announces its genre membership explicitly, it fails, or perhaps refuses, to substantiate fully its initial self-categorization. Indeed, its ambiguous adherence to the premises of this event-focused genre highlights how the use of a particular generic format to organize narrative material can serve to foreground and conceal, activate and deactivate ideological meanings.

There is a scene in Christoph Hein's 1982 novella Der fremde Freund that highlights a particular problem of socialist East Germany in its stagnant and stifling final years. A man called Henry, the strange or distant friend of the novella's title, watches a couple of young people hanging around doing nothing in a dingy dance hall. Speaking to some policemen sent to the discotheque, who believe that young people just want to get drunk and get into fights, Henry claims that the apathetic members of this group are waiting for something to happen: "They hope that something will occur. Anything, perhaps their lives." The policemen exchange knowing glances; this is not a politically prudent thing to say.

The scene captures one of the major themes of Hein's novella, something one could perhaps call the dreariness of oppression in the GDR. Dictatorial political regimes do not always make themselves felt through cruel curtailments of personal freedom. They sometimes suffocate their subjects slowly, inducing states of exasperation and lethargy rather than fear and horror. In its final decade, the socialist regime in East Germany ruled over drab towns and cities whose inhabitants did not live on the brink of starvation or experience radical purges, but did have to endure travel restrictions, recurrent shortages and permanent inefficiencies, negotiations with the inflated bureaucracy, and of course surveillance by the fastidious secret service. The ageing elite had shed its earlier 
technological and political ambitions and "moved into a period of cozy morbidity,", focusing on cutting its population off from its Western neighbors, infiltrating and dissolving emerging independent social groups, all the while offering individuals modest economic benefits. ${ }^{3}$ Looking back at this calcified party state, in which people were pushed back or retreated into small cells of private wellbeing, historians have often suggested hybrid labels for the political system, such as "welfare dictatorship", or "participatory dictatorship." 5

The question of this paper is how an author might try to represent this oddly avuncular oppression seemingly based on the congruence between the regime's habit of exercising power and the power of habit among the population. ${ }^{6}$ In general, authors might not want or even be able to confine themselves to presenting the kind of patient examination of entrenched institutions and mentalities that a portrayal of societal stagnation probably calls for. But when the GDR had entered an epoch of plainly gerontocratic management and small-scale bribing of the population, more satisfyingly melodramatic renditions of evil would perhaps no longer do justice to the often tired but fairly sure, predictable, and pedantic way that the regime deployed its resources of coercion and persuasion. Such renditions would of course also have been immediately blocked by the system of censorship.

Christoph Hein's novella Der fremde Freund is, I submit, about this problem. It poses the question of how to represent sociopolitical conditions in the GDR and the special kind of numbness that they seem to produce, linked as it is to the particular kind of hope and promise the nation once inspired. How, the text asks, does one describe, in narrative form, the peculiar way that people could suffer in and from the GDR? Which storytelling templates and types of plots, if any, can clarify and render comprehensible its forms of alienation?

Claudia, the female narrator of Hein's novella, does suffer in a strangely apathetic way. The novella is a portrait of malaise. As such, one can approach the text as a rudimentary indictment of the socialist society in which such malaise was possible. Yet it remains somewhat uncertain exactly what Claudia suffers from, where one should locate the sources of her dull pain, and who or what bears responsibility for the distress. This is, one could say, the central political problem of the text. 
The novella does point to causes of suffering, or indicate possible diagnoses of Claudia's condition (the clinical language is not inappropriate here). The answers on offer in the text, however, may lack persuasive force. To begin with, Hein's novella is just that, a novella. Its full title reads: Der Fremde Freund/Drachenblut. Novelle. ${ }^{7}$ In the German tradition, of which Hein was surely not unaware when writing, the novella is the genre devoted to the unprecedented happening, to the exceptional event. ${ }^{8}$ In contrast to longer epic forms, the concise and concentrated text of the novella focuses on recounting or searching for a remarkable incident and tracking its peculiar effects rather than, say, the slow development of a character toward maturity, the rise and decline of families, or the panoramic depiction of a social landscape. In the novella, "everything is organized around the question, 'What happened? Whatever could have happened?",9

Given the constraints of this genre program, the dominant issue of Hein's text, the narrator's deep and eerie unease, is connected to an event. There must be some central incident that can be understood as the cause of present behavior, the narrative reconstitution of which explains the narrator's emotional profile and pattern of action. ${ }^{10}$ Hein's text is a novella in that it presents an event supposed to explain the protagonists' condition; at one point, something did occur.

Yet there is also, I argue, something about the text's depiction of a muted atmosphere and the narrator's irremediable disconnection and frozen pose of refusal that is not fully illuminated by such a presentation of a singular event. The unprecedented happening that took place and is retrospectively constituted in the text cannot completely account for the attitude of the character that speaks in it; the haunting tonality does not seem to emanate from one exclusive source. This is all to say that the central political problem of the text — what produces suffering? — remains unresolved.

Der fremde Freund may count as a paradigmatic novella of the postwar period, ${ }^{11}$ but it fails at or refrains from substantiating its self-labeling in politically consequential ways. This is not, however, a mere assertion, made around three decades after the novella's publication. On the contrary, the problem of a curious excess of alienation in the text emerges most clearly when one juxtaposes the initial critical reactions in East (largely skeptical) and in the West (largely positive). As we shall see, ideological commitments correlate with the easy acceptance or irritated rejection of the text's 
operations of self-categorization, thus offering an indication of the ideological dimension of genre itself.

It is even in and through the symptomatically divergent responses to the text in reviews from the GDR and the FRG that one can best come to understand its ambiguous handling of genre. In Der fremde Freund, the novella form becomes visible as a particular device to organize materials in one way rather than another, steer the course of interpretation, foreground or conceal political utterances, and activate and deactivate ideological meanings. ${ }^{12}$

\section{The Novella as Pathography}

Christoph Hein's Der fremde Freund is a text with a particular sound: the laconic, sometimes sarcastic voice of its female narrator, Claudia. It is through her terse pronouncements on the world, the studied matter-of-factness of which rings increasingly hollow, that the reader learns about her character and its relationship to the history and society of the GDR. Here is an early and often-quoted passage, which contains something like Claudia's statement of purpose:

Die Mieter in diesem Haus wechseln sehr häufig. Die Jungen heiraten, und die Alten sterben. Man wohnt hier nur auf Abruf. Zwischenstation. Es lohnt sich nicht, Bekanntschaften zu machen, was ich ohnehin nicht schätze. Bekannte, die im gleichen Haus wohnen, haben immer etwas Aufdringliches. Allein der Umstand, daß man sie täglich treffen konnte, die Unausweichlichkeit eines Gespräches, einer erforderlichen Freundlichkeit belastet solche Bekanntschaft. Wenn man geschieden ist, wird der Drang, irgendwelchen gleichbleibenden, täglichen, unvermeidlichen Verbindlichkeiten zu entgehen, offenbar größer. Ich will nicht mehr Tag für Tag in fremde Gesichter starren, die nur deswegen zu mir gehören sollen, weil es immer die gleichen sind. Unveränderliche Vertrautheit, die ich ausgeliefert bin. Ich ziehe das diskretere Verhältnis zu den Möbeln in meiner Wohnung vor. Sie sind unaufdringlicher. ${ }^{13}$ 
In the passage, Claudia's conveys the following information: she is divorced, lives alone in an apartment complex with small cells for renters in transition, and is excessively concerned with maintaining distance to others. ${ }^{14}$ She is, one could say, almost suspiciously eager to make clear that she regards contact-seeking people as a nuisance. In the course of the novella, more of the same is revealed about Claudia's familial life, social position, and tendency toward self-isolation. She does not want to remarry or have children, and limits herself to relationships with men who agree to tag along for some vacationing and perhaps offer regular sex. She is evasive and embarrassed in interactions with her parents, treats her job as a physician at a city hospital as a set of routines divorced from the idea of doing good, remains passive and observant in interactions with acquaintances, and withdraws behind a screen of noncommittal phrases whenever someone - an elderly neighbor, a friend of a friend, a wife of a colleagueapproaches her hoping for some consolation or at least understanding.

Claudia wants cool, sober, indifferent surroundings. She pursues a program of minimal emotional attachment. She wants to avoid sincere and fervent dedication to another person, but considers even a relationship of casual acquaintance a cumbersome obligation. And as we learn from the passage quoted above, something like a brief elevator conversation also strikes her as a form of cloying entanglement.

Unsurprisingly, interpretations of the novella have frequently turned into diagnoses. What exactly is wrong with this person? Readers and scholars have suggested different personality descriptions, including some more technical psychiatric labels.

Claudia leads an "empty, meaningless, crippled existence"15 or exhibits an "anaesthetized moral connection" "16; she suffers from neurosis, narcissism, or egomania, is a schizoid personality or, more plainly, a monster. ${ }^{17}$ Then there is the associated problem of where to locate the sources of her deformation: What caused Claudia to retreat from a life supported and enriched by enduring emotional ties to others? What constellation of factors in her upbringing or what deficient milieu, society, or age conspired to shape this personality?

But before one goes looking for answers to these questions, one should note that the novella really does want the reader to pursue them. The text insistently invites us to ask: What is wrong with Claudia? Why is she like this? Hein prepares for such a 
psychological approach by means of a cunning textual strategy. He makes sure that the narrator's cover-ups, inconsistencies, and justifications are eminently noticeable, which prompts one to view Claudia as an object of analytic efforts. ${ }^{18}$ Hein is a master of mimicking hollow-sounding declarations of contentment: "Ich wüßte nichts, was mir fehlt. Ich habe es geschafft. Mir geht es gut."19

Constant assurances of calm indifference are also pierced through by occasional reports on episodes of inexplicable nervousness, fantasies of regression, and consumption of alcohol and sedatives. All this allows the sensitive reader to hear, an early reviewer wrote, the cries that Claudia never lets out. ${ }^{20}$ We learn from the brief glimpses of inconsistent behavior that she really is far unhappier than she explicitly states. In other words, the text tells the reader not to believe the surface of Claudia's pronouncement, but to approach them as discursive symptoms of barely contained desperation. ${ }^{21}$

Der fremde Freund persistently presents itself as something of a case study, a representation of symptoms. The qualities of Claudia's discourse compel us to ask what she is working so hard to conceal. What is the key to her behavior? Or, since this is a novella, a genre organized around the event, the question can be rendered thus: "Whatever could have happened for things to have come to this?"22

The answer that the novella eventually provides to the questions it forces upon us (what is wrong with Claudia, or, what happened to her?) should be unsurprising to contemporary readers acquainted with the rise of the trauma concept in literary studies: Claudia was deeply wounded at a young age. ${ }^{23}$ Her tendency to rebuff any attempts at connection, as well as her unwillingness to contemplate past troubles, are symptoms of serious emotional injury inflicted upon her during a sensitive phase of development. And the reader is informed of this past, so as to be able finally to match her emotional withdrawal with a narrative of damaged trust and harmful rejection.

This story is delivered in the longest chapter, about a hundred pages into the work. As if pulled by irresistible gravitation, Claudia in this chapter journeys back to her childhood town together with Henry, allegedly puzzled by her own impulse to explore the locations of her own past. It is this trip that then provides the occasion to recount a series of connected happenings that determined Claudia's psychological profile and subsequent life course. ${ }^{24}$ 
Thinking back to exceptional moments during her upbringing in a small East German village in the 1950s, Claudia even represents herself as injured by a series of disruptions that are directly correlated with GDR-specific political trends. What happened? First of all, her parents and teachers forced her to break up an intimate, nearsymbiotic friendship with another girl, Katharina, whose family was denounced and driven out of the country because of their Christian faith and lacking allegiance to socialism. In another episode presented in the same chapter, and similarly connected to the regime's campaign of eliminating antisocialist elements in the newly founded East German nation, an uncle whom Claudia loved was indicted for collaboration with the Nazis and imprisoned, without receiving any tokens of support from Claudia's parents.

These two stories of personal stress and disrupted intimacy are, moreover, prefigured by childhood memories of general conditions and historical events, first recollections of the rigid socialization in parts of the GDR school system epitomized by a harsh gymnastics teacher, and second a story of how a Soviet tank drove into the village and parked in the central square, to establish beyond doubt who ruled over the land. In the space of a single chapter, then, the reader learns about a series of ideologically colored incidents that severed Claudia from sources of joy and comfort but also symbolically established relationships of subordination and recurrent intimidation.

Hein lets Claudia shed light on her tendency to remove herself from others by having her verbalize shattering moments of penalized affection in her early life. If she adopts a strategy of consistent self-isolation as an adult, this is because she was herself isolated in her youth, torn away from people she cared about and depended on. She keeps

repeating the disastrous complex of events. ${ }^{25}$ Narratively, Der fremde Freund thus first presents us with an enigmatic personality, a portrait of a damaged individual, and then makes an explanation available to us in the form of reappearing memories. Claudia's personality once crystallized around a core of hurtful events; the silence is broken, the secret unveiled, the wound revealed. Or so the novella wants us to believe.

\section{Tacked-On Trauma: East/West Reception}

The problem with Der fremde Freund is that the estrangement and buried anxiety that speaks in every paragraph of the text hardly lets itself be explained so easily. The 
reported events outlined above do not stand in a relation of plausible proportion to the muted tone and bleak observations that pervade the entire text, and it is even doubtful whether a person as repressed as Claudia would be able to produce the report in the first place. For more than one reason, the unveiling of the secret, the presentation of the key events, fails to persuade. These assertions, I should immediately add, are not mine. They are rather the sometimes explicit, sometimes implicit judgment of a wide group of early readers, who, from very different ideological vantage points, argued that the supposed revelation should be discounted or at least downplayed.

On both sides of the wall, reviewers thought Der fremde Freund's attempt at offering a background to Claudia's indifference remained insufficient, even unpersuasive. Let us first examine the way that critics in the GDR expressed the suspicion that Claudia's deformed emotional and moral sensibility was not rendered fully transparent by her own account of her past.

To more or less officious critics in the GDR, many aspects of Hein's novella proved irritating and unsettling. The narrator's complete disinterest in cooperation at the workplace and in the neighborhood, and refusal of all political activity, disqualified her as a model of conduct. Her demonstrative blankness repudiated the existence of an allencompassing solidarity in GDR society. At the very least, Claudia's frozen emotional life indicated that socialist society was powerless to eliminate cases of psychosocial illness. Clear demonstrations of profound indifference, one could say, were politically subversive in the GDR. In a nation where the party state exercised control over most aspects of society and concealed mistakes and malfunctioning with propaganda, mere ennui reflected poorly on the ruling elite.

It would be quite wrong, however, to dismiss the GDR critics' reactions to Hein's novella as so many attempts to neutralize its critical force. The interplay between Hein's narrative and the reading habits and interpretive strategies available to GDR reviewers and scholars was complex. Going through the debate, one can even speak of a mutual exposure of limits: Der fremde Freund certainly triggered dogmatic responses, and yet predictable ideological approaches did, I would argue, highlight interesting features of the text. GDR critics observed how the overall depiction of Claudia's condition and her own account of the events during her upbringing did not fit together. There was, they 
claimed, a curious noncorrespondence between Claudia's reported teenage experiences and her adult emotional life.

Writing in the literary journal Weimarer Beiträge, Bernd Schick claimed that Hein breaks with the rest of novella once he lets the narrator articulate injurious childhood experiences explicitly and in detail. Instead of continuing to let the reader glean what remains unsaid in Claudia's tightly controlled staccato-like speech, Hein has her provide a full-fledged causal narrative that merely feels forced or "nachträglich aufgesetzt." 26 The moment Hein suggests, through the discourse of his narrator, that her condition can be traced back to particular political events in GDR history, the text threatens to lose its stylistic and narrative coherence.

In another pro-et-contra piece about the novella for the same publication, Gabriele Lindner likewise questioned the overly neat link between a few clearly contoured, lucidly captured childhood experiences and an entire adult life program of rigidly observed emotional distance. The novella insists that Claudia's alienation is the consequence of discrete and accessible episodes in the past, but this, Lindner averred, simply constitutes an arbitrary negation of human autonomy rather than a differentiated analysis. ${ }^{27}$ To GDR critics reading Der fremde Freund, Hein presented a sort of tacked-on trauma.

This critical point of view could, I think, stem from an underlying resistance to what we could call trauma narratives that may be inherent to a socialist outlook. As Lindner's response implies, accounts of how particular events in personal history cripple individuals for life presuppose the fragility of human agency and the intractability of pathologies to broad social and political reforms that could be difficult to accept from the perspective of socialist-materialist accounts of how socioeconomic conditions shape and can be shaped by human agents.

In light of this, it is perhaps unsurprising that reviewers in West Germany found no particular fault with Hein's way of structuring the novella. In newspaper reviews and early scholarly commentaries published in West Germany, Hein's work was received as a tightly composed, fully persuasive account of social seclusion and emotional disconnection that also highlighted the damage done to young people by a coercive regime rooting out rival ideologies. Yet in the West, too, the early compound of events and the adult life program of withdrawal appeared rather loosely connected. Claudia's 
story of the shocks and disappointments of her upbringing in the GDR met with acceptance but was still viewed as something of a discrete side theme rather than as the ultimate explanation of her anomie.

Writing in DIE ZEIT, for example, the critic Rolf Michaelis admitted that Claudia's account of her hurtful socialization in the early GDR throws light on the silence of her generation. But at the same time, Michaelis denied that the novella should be exclusively understood as a "Klagelied über die Verhältnisse in der DDR." ${ }^{.28}$ In fact, Hein's "Geschichte einer Lebensverhärtung" could, he argued, be read as a portrait of estrangement in more than one nation or system, and the novella would resonate with a West German audience. ${ }^{29}$ In the Frankfurter Allgemeine Zeitung, which also published Hein's entire novella in daily segments, Uwe Wittstock similarly spoke of the text's broad relevance: "Sie [Claudia] lebt in Ost-Berlin, doch von einigen Details und Requisiten abgesehen gibt es nichts in ihrer Geschichte, keine Szene, die nicht ebensogut hierzulande spielen könnte. ${ }^{\prime 30}$ Der fremde Freund showed the reader an entire society no longer held together by strong bonds of friendship and love, intergenerational ties, cohesive families, or unifying symbols and as such it should be welcomed as a depiction of how emotional and spiritual desolation could spread in a modern world that knew no obvious material need. Claudia's condition was not system specific. Hein had, Wittstock and others suggested, succeeded in crafting an unlocalizable case study of alienation. ${ }^{31}$

Despite different vocabularies and attitudes, then, West German critics were in a strange sort of agreement with reviewers in the East. Both groups claimed, in different ways, that the novella did not portray an illness peculiar to the GDR, despite the fact that Hein lets his narrator recount exactly how the ideologically informed policies of the early GDR mauls the soul of a young citizen. As the novella traveled across the GermanGerman border, Hein's perceived failure to connect Claudia's psychological condition to specific episodes in GDR history turned out to be his success in speaking about the general problems of modern societies, but no critic seemed to believe fully in the force of the all-important event, the separation from symbiotic friendship and family relations.

GDR critics, one should reiterate, were more attuned to the particular problem of genre in the text and its potential inconsistencies. They explicitly addressed the visible seams in the text, its less than satisfying attempt to stitch together a psychological 
condition with a particular cluster of past events. In the West, the text was simply accepted both as an account of GDR-specific socialization and as a widely relevant portrait of modern malaise, although this positive response may actually tilt toward incoherence. Claudia's suffering was, apparently, both a result of conditions unique to the GDR and a pathology shared by people in all modern, urbanized, and industrialized nations - and hence not unique to the GDR. Hein managed, so it seems, to confirm the critics' preconceptions both of GDR brutality and of meaninglessness in modernity, and the comfort of easy recognition of well-known facts concealed the problem that these two aspects may not be entirely compatible.

\section{as Occurrence}

Against the background of the converging German-German judgments of Der fremde Freund, one can speak of an excess of alienation in Hein's text, a sort of floating, apparently unexplained estrangement and anxiety. The past occurrences fail to absorb the entire discourse, to convert Claudia's peculiar way of behaving and reasoning into emanations of early psychological injury sustained in the GDR. It is in this sense that Hein's Der fremde Freund slips out of the novella genre; the determining event does not work as a key to the text.

The question is, however, why Hein chooses to impose the novella form on his material, or what work the genre is supposed to perform for the text. One answer is that the novella serves to focus but also to contain the dissent it articulates. Der fremde Freund levels an insistent critique at the GDR: Hein points to the party state as culprit or source of suffering and quite explicitly lays the blame for Claudia's condition on the GDR system. But as we have seen, the novella represents the party state, the reach of its policies and force of its decisions, most openly through Claudia's retrieved memories of her childhood socialization; all the fateful disruptions afflicting her can be traced back to the new socialist state intent upon enforcing its agenda in the early 1950s. That is to say that Hein's text openly depicts the individual's relationship to the party state, but not as an ongoing negotiation of a set of constraints and routines in the present or a form of friction with institutions and their representatives. Instead he compresses this subjectstate relationship, renders it in the form of a single bundle of episodes and locates it in the 
past, so that it appears as a submerged but not inaccessible memory of a disrupted childhood.

The GDR party state is in other words far from absent in Hein's text, but its activity is pointed to in an episode that occurred well before Honecker's rule, in the 1950s, as the GDR was still transitioning into socialism, and identifying and dealing with Nazi supporters and disloyal elements. The regime did intervene in Claudia's life and determined the course of her life, but this happened at a circumscribed moment in the past. To put it differently, Der fremde Freund first hints at but does not articulate an account of the sociopolitical production of self-isolation by letting Claudia voice her continuing unease and estrangement, only to finally press the sociopolitical conditions of the GDR into the event-focused genre of the novella. Fully aware of the system of censorship, ${ }^{32}$ Hein may have eschewed a more direct indictment of the present and, through use of the novella form, located the most obvious crime of his text in an earlier period.

In keeping with the novella as a brief narrative centering on a remarkable event, the text portrays the party state as an immense power in the narrator's life, but chooses to represent this relationship in the form of a compound of life-defining past events. For scholars taught to appreciate the relevance of trauma as a category of literary and cultural studies, Hein's novelistic emphasis on a past event laboriously uncovered late in the text may seem like an interesting and valuable revelation. Indeed, readers have welcomed Claudia's narrative as a story that grounds Hein's novella in a specific GDR history: "1953," one scholar writes, is "the turning point in Claudia's life and in the novella itself" and moreover "provides an important structural connection between the theme of alienation and the historical context." 33 To the critics responding to the work in the early 1980s, however, the trauma narrative seemed flimsily attached to a text that never ceases to point to, but also never quite delivers, a broader picture of the current sociopolitical production of apathy and indifference.

Fritz Breithaupt has argued that the retrospective constitution of traumas in the novella genre functions as an excuse for the individual, whose aberrant behavior comes to appear coherent and comprehensible once the injury that shaped it is unearthed. ${ }^{34}$ But in this case, the trauma does not just persuade the readers to soften their judgment of the 
individual protagonist. It also moves the center of gravity from the present to the past, taking some of the pressure off real existing socialism in its final decade. Claudia may not be living a fulfilled life in 1980s Berlin, but Hein lets her detect the root of her predicament not in the current conditions but in the past, not in the era of Honecker but in the era of Ulbricht.

\section{Narrating Hegemony}

But if we look beyond Der fremde Freund's inserted story of early damage, follow the lead of the GDR critics and discount it, can we then catch a glimpse of how Claudia suffers not just in, but also from late socialism? To see late socialism in the text, let us first ask how the GDR regime maintained its power over the population and achieved stability in its final decades. According to the historian Mary Fulbrook, the regime's grip on GDR citizens rested neither on the use of violence nor on genuine popular approval. Instead, the regime made itself identical with the structures and routines of the everyday, becoming something like a fact of life to be dealt with in the best possible way rather than an actual form of rule to be resisted or supported:

Stability is predicated on a form of Anpassung, a preparedness to go through the motions, to participate in the rituals and acts of obeisance of everyday life - in short, a willingness to ensure that one actually has as easy a life as is possible under the given political conditions. This is certainly neither a case of coercion, nor of consent: there is no belief in the legitimacy of domination, no positive support of the system in principle, nor is there necessarily a daily fear of repression. . . Rather, it is simply a form of often unthinking - even unconscious - conformity, of co-operation with the often implicit rules of the game. ${ }^{35}$

According to Fulbrook, the GDR regime had sunk into social life in a way that removed it from the arena of political contestation or participation. ${ }^{36}$ Rather than presenting itself as a set of ideas, values, institutions, and measures to be ratified or rejected, or that had to be succumbed to because of an always-present threat of violence, 
the regime became something with which one had to reach accommodation. We know how the everyday works: to get by from one week to the next, one has to step out of bed in the morning, make it to work, complete the tasks with reasonable speed, keep up a decent atmosphere with one's workplace colleagues, and so on. The system of rule in the GDR, Fulbrook implies, sustained itself by becoming something else that "one just had to put up with," and by occupying the regularities and repetitions of daily life and exploiting people's tendency to settle into near-mechanical patterns of behavior. ${ }^{37}$ Late socialism was just the way things were. ${ }^{38}$

This rule by routine and barely articulated concord is on display in Hein's Der fremde Freund, for Claudia is precisely a person who "goes through the motions"; or she is someone who has been reduced to pulling herself through the everyday without enthusiasm but also without any fear. ${ }^{39}$ She goes to work, interacts with her nurse, treats her patients, eats lunch with her colleagues, and every one of these scheduled and predictable encounters elicits some minor reaction in a gray emotional palette: irritation, annoyance, coldness, none of which disturb the general attitude of studied indifference. In the final pages of the novella, she even declares: "Mich wird nichts mehr überraschen." ${ }^{40}$ At the end of the event-focused novella, Claudia asserts that nothing more will truly happen to her, that no further events will take place in her life. The novella thus ends with a statement on the future impossibility of a novella. ${ }^{41}$

Hein's portrait of Claudia, the observations of her slightly dismissive but ultimately apathetic acceptance of the structures and routines of her social world, is the presentation of a personality type partly molded by and responsive to the GDR regime. A party state that has to a large extent ceased to intimidate its subjects with constant threats of violence, ${ }^{42}$ but also ceased genuinely to solicit their support, needs people prone to accept the tedium of ongoing social life and follow institutionalized patterns of behavior without much overt pressure. ${ }^{43}$ Such a party state even prefers the half-hearted, affectless but quiet subjects to the more genuinely engaged and zealous ones, for the reason that fervent support of political principles can more easily turn into dissidence. ${ }^{44}$ (It should also be added that Hein, in 1989, when he could speak freely to his East German public, above all wished for a democratization and politicization of the GDR and a reactivation 
of its subjugated citizenry, now free to devote itself to fulfilling the aspirations of genuine socialism. $^{45}$ )

The more revealing and perhaps the more radical depiction of late socialism, then, comes at the beginning of the Hein's Der fremde Freund, that is, before the reconstructive work of the novella has taken over the text. It is there, in Claudia's initial reports on the monotony of her daily life, that we get to glimpse a picture of hegemony as exercised in the GDR. This chilling part of the text traces the psychological profile of someone who fits the peculiar requirements of intentionally tedious rule in late socialism.

Hegemony that rests on recurrence and routine, hegemony that works in the medium of the ongoing and wants not to occur, might resist attempts to make it visible in the form of a suspenseful or surprising narrative; it endeavors to be unspectacular. ${ }^{46}$ In Der fremde Freund, the reconstitution of a traumatic event can even be viewed as an attempt to deal with, or perhaps avoid, the problem of sustaining a narrative whose focus would be the "Ereignislosigkeit" of late socialism. ${ }^{47}$ The secret of Hein's novella is not the secret that is eventually revealed, the forgotten but finally reconstructed episode supposed to shed light on everything that came before it, but the more elusive secret of rule entrenched in the everyday. For political and for narrative reasons, Claudia's fate is made to fit the demands of the novella, a textual form that focuses on an unprecedented event and its long-term effects. Her numb way of going about her business is not, in the end, a means to negotiate late socialism as a form of hegemony, but rather a mystery dispersed or an aberration explained, in the course of the narrative, by the presentation of the damage done to her at an earlier time.

\section{The Import of Critique}

At the end of Der fremde Freund, Claudia articulates yet another string of hollowsounding assurances as to her wellbeing. She emphasizes her more than adequate level of material comfort and does not fail to mention the opportunities of consumption afforded her in her milieu:

Ich bin ausgeglichen. Ich bin einigermaßen beliebt. Ich habe wieder einen Freund. Ich kann mich zusammennehmen, es fällt mir nicht schwer. Ich arbeite gern in der 
Klinik. Ich schlafe gut, ich habe keine Alpträume. Im Februar kaufe ich mir ein neues Auto. Ich sehe jünger aus, als ich bin. Ich habe einen Friseur, zu dem ich unangemeldet kommen kann, einen Fleischer, der mich bevorzugt bedient, eine Schneiderin, die einen Nerv für meinen Stil hat. ${ }^{48}$

The text wants us to read the emptiness that speaks in this mechanical list of advantages and benefits; this is clearly not a fulfilling life. Provoked by the novella's tone, early respondents in the GDR protested that the narrator did not take advantage of the fullness of authentic possibilities offered by socialist society. ${ }^{49}$ But perhaps the opposite would be more correct. Claudia very much exploits the possibilities in East German socialism, for regardless of how ghostly her existence is made to appear, she is a socially independent and materially reasonably well-off person. ${ }^{50}$ They are undeniably there, the casual social and sexual connections, the professional career, the goods and the services. ${ }^{51}$

So what is the problem with Claudia? The problem is, as Der fremde Freund insists through its deployment of the novella form, that Claudia was damaged early on. And, we can now add, her professional career and her acts of consumption cannot possibly heal her. Comfort alone does not have the power to bestow meaning on her injured existence.

Yet this reading does not fully capture the ideological trick of the passage. By letting Claudia speak of her perfectly pleasant life including her access to affordable goods and services through a decent set of contacts, Hein in effect turns what looks quite like a critique of consumption against the welfare dictatorship of late socialist society. ${ }^{52}$ Insofar as a citizen of the GDR with its planned economy can still legitimately present her life as a string of transactions, socialist society seems as vulnerable to a critique of consumerist attitudes as its free-market neighbor to the west. As readers in the West were quick to point out, and quick to celebrate, the message of Hein's novella was equally relevant in the East and in the West; it revealed a boredom without borders.

The GDR and the FRG, these readers in the West could imply on the basis of the text, did exist on a continuum; they were both modern rationalized societies offering their members opportunities for consumption, and these members were then also likely to 
exhibit similar pathologies. But what the critics in the West did not and perhaps could not discern was that the ideological force of the passage lies precisely in the implied denial of a systemic difference between socialism and capitalism. If the same critique applies across the political divide, this divide matters less than one might think, and hence socialism is deprived of specificity; it exists only as a meager version of the West. ${ }^{53}$

In Der fremde Freund, the GDR has failed not only to prevent or alleviate Claudia's malaise, but insofar as she has come to present herself as an agent in relation to an array of goods and services, it seems to have failed to establish itself as a full-fledged alternative to a capitalist system. The novella suggests what Hein, a committed socialist, would later state openly in his speech at Berlin Alexanderplatz on November 4, 1989: GDR society was simply not a socialist country. ${ }^{54}$ When GDR critics argued, with some irritation, that Claudia does not truly live in socialism, does not make use of its possibilities for living a dignified life, they were perhaps nervously responding to the question posed by Hein's redeployment of a critique of consumption: if one can conduct one's life in this way, in what sense is this the socialism we hoped for?

The passage quoted above recapitulates the strategy of the novella as a whole, or rather the strategy that consists in the very use of the novella form. As suggested earlier, the novella genre is a device with which Der fremde Freund seeks to solve problems of narrating late socialism, for the format allows Hein to explain Claudia's condition by reference to an earlier historical phase rather than attribute it exclusively to current hegemony, to reconstruct a buried chronology rather than diagnose a present. The choice of the novella form thus partly seems to constitute a semi-retreat from outright political provocation, a slightly evasive literary handling of party hegemony that the text nonetheless does record. Yet the novella form itself also does propose a peculiar critical stance vis-à-vis the GDR, a point that was not lost on reviewers in the GDR.

How does the novella set-up suggest a critique of the GDR? By presenting a story of a single vulnerable subject wounded by an overpowering regime acting through parental and educational authorities, a subject who finally travels back to the site of the wounding to articulate, with suspicious fluency, the secret of her existence, Hein's text installs and confirms a focus on the individual, weak in the face of a state with crushing resources of coercion (but possibly curable through some therapeutic process). Through 
the narrator's reconstruction of the determining event, a clash between a trusting soul and a rigid regime, Der fremde Freund at least overtly commits itself to a particular conception of the individual who stands against the far-reaching but contoured and alien state. In this way, Hein's novella stages a "kritische Auseinandersetzung" with the GDR, but its narrative actually follows a "westlichen Muster," as Peter Brenner laconically states in his literary history. ${ }^{55}$ Yet Brenner's statement must be slightly modified: Hein's "critical engagement" with the GDR consists precisely in the use of a "western pattern," for this use signifies a failure of the socialist nation to dissolve and move beyond the antagonism between the individual and the structures of the party state.

In East Germany, this insertion of the novella form was, with some right, criticized as an ideologically motivated formal choice. One critic spoke of Hein's "demonstrative Genrebezeichnung" and pointed to the narrative's novelistic insistence on the force of one group of events over and above the continual exercise of private and public autonomy in the present. ${ }^{56}$ In contrast, West German critics warmly welcomed the novella as a bleak report from the GDR and also as a picture of modern isolation and alienation. But then this very success in the West relied on the novella's prior import of a Western-style account of how the personhood of vulnerable individuals is formed and deformed in a society that does not adequately respect them. The text was so easily consumable in the West because the narrative template and the political assumptions inherent in it already belonged there. When the novella came to the Federal Republic and exposed the East as something of a drabber and more brutal version of the West, the text was in some sense just making its way back to its ideological home. Hein was, one could say, returning a format he had borrowed to level an internal critique of the GDR. ${ }^{57}$

Ironically, the specifically socialist dimension of Hein's novelistic critique of GDR was lost in the process of this assimilation of the already assimilated, for no West German reviewer spotted Hein's denial, through the novella form itself, of GDR's claim to distinction. The familiarity of the story's design, its fit with ideological assumptions in the West, obscured the more fundamental point of the critique: the deeply disappointing nonemergence of a socialism that would have lived up to its name.

Hein's Der fremde Freund counts as a paradigmatic postwar German novella and an insightful — and devastating — account of life under late socialism. The work deserves 
its status. Yet, the discernible imposition of the novella genre upon the material of the text partly constitutes a method of not narrating socialism in the double sense of disputing the regime's alleged achievements and distracting from its manner of exercising power. Using the novella form to concentrate on the isolated individual permanently wounded by a cluster of past incidents, Hein critically implied that the GDR had not moved beyond the rigid antagonisms of Western society, but he also deflected attention from its peculiar rule by routine in the present. As a particular way of organizing and presenting a story, the novella thus narrates neither the regime's specifically socialist ideal nor its peculiar kind of entrenchment, neither solidarity nor hegemony.

\footnotetext{
${ }^{1}$ Christoph Hein, Der fremde Freund/Drachenblut. Novelle (Frankfurt am Main: Suhrkamp, 2002), 107.

${ }^{2}$ Benjamin Robinson, "Planners, Pillars, and Pretenders: Socialism Between Enlightenment and Sovereignty," Modernism/Modernity 11, no. 2 (2004): 344.

${ }^{3}$ Sigrid Meuschel refers to the "Ausbau der Staatssicherheit" and the "Sozialpolitik" in the GDR as twin aspects of the regime's "Reformvermeidungspolitik." See Sigrid Meuschel, "Überlegungen zu einer Herrschafts- und Gesellschaftsgeschichte der DDR," Geschichte und Gesellschaft 19, no. 1 (1993): 12.

${ }^{4}$ Konrad Jarausch, "Fürsorgediktatur," Docupedia-Zeitgeschichte 11, no. 2 (2010), http://docupedia.de/zg.

${ }^{5}$ Mary Fulbrook, The People's State: East German Society from Hitler to Honecker (New Haven, CT: Yale University Press, 2006).

${ }^{6}$ In her 1995 analysis of the power structure of the GDR, Mary Fulbrook focuses

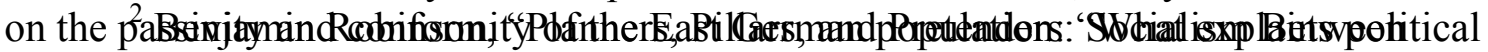

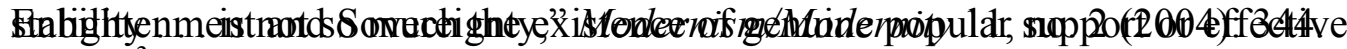

${ }^{3}$ Sigrid Meuschel refers to the "Ausbau der Staatssicherheit" and the "Sozialpolitik" in the GDR as twin aspects of the regime's "Reformvermeidungspolitik." See Sigrid Meuschel, "Überlegungen zu einer Herrschafts- und Gesellschaftsgeschichte der DDR," Geschichte und Gesellschaft 19, no. 1 (1993): 12.

${ }^{4}$ Konrad Jarausch, "Fürsorgediktatur," Docupedia-Zeitgeschichte 11, no. 2 (2010), http://docupedia.de/zg.

${ }^{5}$ Mary Fulbrook, The People's State: East German Society from Hitler to Honecker (New Haven, CT: Yale University Press, 2006).

${ }^{6}$ In her 1995 analysis of the power structure of the GDR, Mary Fulbrook focuses on the passivity and conformity of the East German population: "What explains political stability ... is not so much the existence of genuine popular support or effective ideological indoctrination, nor constant fear of violence and repression, as simply conformity, political passivity, and the fragmentation and easy suppression of dissent." Mary Fulbrook, Anatomy of a Dictatorship: Inside the GDR 1949-1989 (Oxford: Oxford University Press, 1995), 273.
} 
${ }^{7}$ The East German title was the Der fremde Freund. When it appeared in West Germany, however, the title was changed to Drachenblut; an earlier book published had the same title. The 2002 Suhrkamp edition includes the dual title.

${ }^{8}$ German handbook descriptions of the novella invariably include references to the genre's "Zuspitzung auf ein markantes Mittelpunktereignis" and cite Goethe's dictum that the novella narrates "eine 'unerhörte Begebenheit." Harald Fricke et al., Reallexikon der deutschen Literaturwissenschaft, volume II (Berlin: Walter de Gruyter, 2000), 726.

${ }^{9}$ Gilles Deleuze and Félix Guattari, A Thousand Plateaus: Capitalism and Schizophrenia, trans. Brian Massumi (Minneapolis: Minnesota University Press, 1987), 192.

${ }^{10}$ In an article on the German novella and the idea of an absolutely central event, Fritz Breithaupt suggests that the Romantic novella involved the reader in the search for some occurrence in the past that would cast light on the aberrant behavior of the portrayed individual: "The productivity of the Romantic novella relies upon readers and their ability to detect causes and determine regularity behind idiosyncratic human action." The genre of the novella, Breithaupt continues, promoted the notion that one can explain seemingly incomprehensible behavior by reconstructing a damaging event that gave rise to it. Fritz Breithaupt, "Machines of Turning Actions into Reactions: The German Novella and the Event," in Romanticism and Modernity, eds. Thomas Pfau and Robert Mitchell (London: Routledge, 2012), 176.

${ }^{11}$ In Hugo Aust's introduction to the genre, Hein's Der fremde Freund, or Drachenblut, is included as a self-evidently central example of the contemporary novella, alongside other postwar works by Friedrich Dürrenmatt, Günter Grass, and Martin Walser. Hugo Aust, Novelle (Stuttgart: J. B. Metzler, 1999), 181.

${ }^{12}$ On genres as institutions designed to regulate reader responses in ideologically significant ways, see Fredric Jameson, "Magical Narratives: Romance as Genre," New Literary History 7, no. 1 (Autumn 1975): 135-156.

${ }^{13}$ Hein, Der fremde Freund, 24-25.

${ }^{14}$ The gloomy presentation of willed isolation in an apartment complex could also be read as a sardonic comment on the blessings of GDR housing policy during the Honecker era. Honecker made the construction of housing "the most visible incarnation" of his new social policy devised to satisfy the East German population, but the construction took the form of standardized housing estates of poor quality. See Jay Rowell, "Knowledge and Power in State Socialism: Statistical Conventions and Housing Policy in the GDR," Journal of Policy History 19, no. 3 (2007): 360.

${ }^{15}$ Julia Hell, "Christoph Hein's Der fremde Freund/Drachenblut and the Antinomies of Writing under 'Real Existing Socialism," Colloquia germanica 25, no. 34 (1992): 309.

${ }^{16}$ Charles S. Maier, Dissolution: The Crisis of Communism and the End of East Germany. (Princeton, NJ: Princeton University Press, 1997), 32.

17 Hannes Krauss' essay on Der fremde Freund exemplifies the tendency to search for a fitting psychological-psychiatric label for Claudia. Leaning on the psychoanalyst Fritz Riemann, he suggests that Claudia is a "schizoide Persönlichkeit." See Hannes Krauss, "Mit geliehenen Worten das Schweigen brechen: Christoph Heins Novelle 'Drachenblut," Text + Kritik 11 (1991): 25. Michael Masanetz's overview of the 
book's reception history includes some further lay diagnoses of Hein's narrator Claudia. See "Kommentar" in Christoph Hein, Der fremde Freund/Drachenblut. Novelle (Frankfurt am Main: Suhrkamp Basisbibliothek, 2005), 205.

${ }^{18}$ Julia Hell writes of the "peculiar construction of a first-person narrative which produces an irresistible pressure to read what is not said." Hell, "Antinomies of Writing," 309.

${ }^{19}$ Hein, Der fremde Freund, 175.

${ }^{20}$ Rolf Michaelis, "Leben ohne Leben: Christoph Heins erstaunliche Novelle," DIE ZEIT, 11 November 1983.

${ }^{21}$ Hein even lets Claudia introduce psychoanalytic themes of repression and the necessary subjugation of an anarchic inner nature for the sake of a functioning, pacified society. She is herself intimately familiar with such deep psychology, although she adapts her knowledge of mechanisms of repression to her personal philosophy of deliberate coldness: "Offenbar erfordert das Zusammenleben von Individuen einige Gitterstäbe in ebendiese Individuen. . . . Ich verdränge täglich eine Flut von Ereignissen und Gefühlen, die mich demütigen und verletzen. Ohne diese Verdrängungen wäre ich nicht fähig, am Morgen aus dem Bett aufzustehen" (98-99). The narrator employs Freudian reflections on the necessity of psychic self-defense to fend off the notion that some form of therapy may be beneficial to relieve pressures on individuals. She argues for bottling it all up.

${ }^{22}$ Deleuze and Guattari, A Thousand Plateaus, 194.

${ }^{23}$ For an example of how the concept of trauma has been applied to the East German context, see for instance the anthology of psychoanalytic writing on political traumatization in the GDR, Traumatisierungen in (Ost-)Deutschland, eds. Christoph Seidler, and Michael J. Froese (Gießen: Psychosozial, 2009). For an overview of the astounding career of the concept of trauma in the humanities, see Wulf Kansteiner, "Menschheitstrauma, Holocausttrauma, kulturelles Trauma. Eine kritische Genealogie der philosophischen, psychologischen und kulturwissenschaftlichen Traumaforschung seit 1945," in Handbuch der Kulturwissenschaften, volume 3, eds. Friedrich Jaeger and Jörn Rüsen (Stuttgart: J. B. Metzler, 2004), 109-138.

${ }^{24}$ According to Cathy Caruth, whose readings of Freud have done much to introduce and promote the concept of trauma in literary studies, the specificity of trauma lies in its persistent unavailability to experience; the event has such power that it does not let itself be recorded by the unprepared and overwhelmed human psyche. She speaks of the "peculiarity of an event whose force is marked by the lack of registration." The phrase "traumatic experience" would thus be an oxymoron. The text Der fremde Freund is not in possession of the trauma concept, but leans instead towards repression or "Verdrängung." See Cathy Caruth, "Introduction," in Trauma: Explorations in Memory, ed. Cathy Caruth (Baltimore: Johns Hopkins University Press, 1995), 6.

${ }^{25}$ Claudia's behavior reveals itself to be a pattern of reenactment triggered by an initial injury, a scheme that Fritz Breithaupt claims the German Romantic novella developed: "One of the most prominent cases of the action-reaction dynamic is the invention of trauma in Romanticism, the idea that certain horrific events in the past can force human beings to involuntarily repeat or re-experience these same events later in life." Breithaupt, "The German Novella and the Event," 176. 
${ }^{26}$ Bernd Schick, “'Der fremde Freund' von Christoph Hein,” Weimarer Beiträge

29, no. 9 (1983): 1651.

${ }^{27}$ Gabriele Lindner, “'Der fremde Freund' von Christoph Hein," Weimarer Beiträge 29, no. 9 (1983): 1645-1648; "Prämissen im Leben," Lindner writes, "stellen sich immer neu"; for her, Claudia is implausibly trapped in a life determined exclusively by childhood experiences. See Lindner, 1647-1648.

${ }^{28}$ Michaelis, "Leben ohne Leben.".

${ }^{29}$ Michaelis, "Leben ohne Leben."

${ }^{30}$ Uwe Wittstock, "Letzte Liebe in der Seelenwüste," Frankfurter Allgemeine Zeitung, 17 September 1983.

${ }^{31}$ Antonia Grunenberg, for instance, argued that Claudia's malaise was socially produced, but claimed that it was not related to features specific to socialism: "Die seelischen Beschädigungen kennen, so scheint es, den Unterschied zwischen Kapitalismus und Sozialismus nicht." Antonia Grunenberg, "Geschichte als Entfremdung. Christoph Hein als Autor der DDR," in Chronist ohne Botschaft. Christoph Hein. Ein Arbeitsbuch, ed. Klaus Hammer (Berlin: Aufbau, 1992), 78. Bernd Fischer similarly suggested that Claudia's suffering, her listlessness and lack of meaningful commitment, had social roots, but claimed that it had little to do with the particular features of socialism: "das Versagen von Liebe und Freundschaft, lustlose Apathie und Orientierungslosigkeit, ... sind Themen, die von der politischen Ausrichtung einer modernen Industriegesellschaft offenbar nur zum geringen Teil modifiziert sind." Bernd Fischer, "Christoph Heins 'Fremde Freundin,"” in Chronist ohne Botschaft, 99. Benjamin Robinson has argued that critics and intellectuals in the West who gloss over systematic differences between the GDR and the FRG and see East German problems as (aggravated) versions of West German problems fail to grant the GDR the status of a distinct sociopolitical system and are in fact engaged in the project of ontologically downgrading real socialism. See Benjamin Robinson, The Skin of the System: On Germany's Socialist Modernity (Palo Alto, CA: Stanford University Press, 2009), 36-37.

${ }^{32}$ Christoph Hein spoke openly about censorship at the GDR author congress in 1987, but in the relatively closed circle of an "Arbeitsgruppe": "Die Zensur ist menschenfeindlich, feindlich dem Autor, dem Leser, dem Verleger und selbst dem Zensor. Unser Land hat in den letzten zehn Jahren viele Schriftsteller verloren, unersetzliche Leute, deren Werke uns fehlen, deren Zuspruch und Widerspruch uns bekömmlich und hilfreich war." Christoph Hein, "Arbeitsgruppe IV Literatur und Wirkung," in X. Schriftstellerkongreß der Deutschen Demokratischen Republik. Arbeitsgruppen (Berlin: Schriftstellerverband der DDR, 1988), 229.

${ }^{33}$ Philipp McKnight, "The Invulnerability of Silence: The Distant Lover," in Understanding Christoph Hein, ed. Phillip McKnight (Columbia: University of South Carolina Press, 1995), 38.

${ }^{34}$ Breithaupt even claims that the "Romantic novella is the genre of general excuseability." See "The German Novella and the Event," 179.

${ }^{35}$ Fulbrook, Anatomy of a Dictatorship, 273.

${ }^{36}$ GDR stability is the key issue for many scholars, such as the historian Andrew Port in his book Conflict and Stability in the German Democratic Republic (New York: Cambridge University Press, 2008). In his review of Port's contribution, Martin Sabrow 
speaks of the "empfundene Normalität der veralltäglichen Herrschaft," Süddeutsche Zeitung, 14 June 2010.

${ }^{37}$ The author Günter de Bruyn has spoken about a kind of a tacit agreement of nondisturbance between the regime and the population, a "Stillhalteabkommen zwischen oben und unten." Günter de Bruyn, Vierzig Jahre. Ein Lebensbericht (Frankfurt am Main: Fischer, 1996), 186.

${ }^{38}$ As the events in 1989 revealed, of course, the GDR and the Eastern bloc was not as stable as it seemed. For an analysis of how the ostensibly solid East German regime could crumble so quickly, see Timor Kuran, "Now Out of Never: The Element of Surprise in the East European Revolution of 1989," World Politics 44, no. 1 (1991): 7-48. Out of fear and desire to conform, people hid their private dislike of the regime, thus "keeping their fellow citizens uninformed about those of their private beliefs that were inimical to the status quo" (32). Once the systematic distortion of private preferences was lifted due to a massive shift in the public discourse, however, "latent bandwagons in formation" could emerge quickly (43).

${ }^{39}$ Phillip McKnight emphasizes how Claudia's life seems made up by daily routines, such as the "routine lunchtime in the clinic's canteen." McKnight, "Invulnerability," 22. Jens-F. Draws mentions how the opening of Claudia's story reads like a "banale Alltagsgeschichte." See Jens-F. Draws, "Hoffnung auf ein Ende. Allegorien der kultureller Erfahrung in Christoph Heins Novelle 'Der fremde Freund,"' Text + Kritik 11 (1991): 7.

${ }^{40}$ Hein, Der fremde Freund, 173.

${ }^{41}$ For a similar argument, see Aust, Novelle, 181.

${ }^{42}$ Stefan Wolle mentions how the regime preferred to avoid overt brutal coercion in its final two decades, opting instead for a more cautious maintenance of power: "die Unterdrückung" assumed "subtilere Formen." Stefan Wolle, Die heile Welt der Diktatur. Alltag und Herrschaft in der DDR 1971-1989 (Berlin: Christoph Links, 2009), 186.

${ }^{43}$ A weakness of the GDR system in its final decade was perhaps precisely that no group in society, not laborers, not small-scale and semi-independent trades- and businesspeople, not administrative employees or service workers etc. really viewed the country as a place that offered much in terms of a bright economic future. Most people went about their business, but without a sense of future improvement and without enthusiasm. In their overview of how different social groups did in fact conceive of different periods of East German history as their "golden years," Thomas Ahbe and Michael Hofmann write "In den achtziger Jahren jedoch konnte die DDR kaum noch zeitgemäße Beteiligungs- und Integrationsangebote offerieren." Thomas Ahbe and Michael Hofmann, "'Eigentlich unsere beste Zeit.' Erinnerungen an den DDR-Alltag in verschiedenen Milieus," Aus Politik und Zeitgeschichte 17 (2002): 22.

${ }^{44}$ Slavoj Žižek claims that a " "sincere' believer in official Late Socialist ideology was ... potentially more dangerous to the regime than a cynic." See Slavoj Žižek, "Attempts to Escape the Logic of Capitalism," London Review of Books, 21 October 2008, 1999. Žižek is here commenting and building upon ideas developed by Vaclav Havel in The Power of the Powerless: Citizens against the State in Central-Eastern Europe, ed. John Keane, trans. Paul Wilson (Armonk, NY: M. E. Sharpe, 1985). 
${ }^{45}$ In his speech, Hein says: "Schaffen wir eine demokratische Gesellschaft . . . ! Einen Sozialismus, der dieses Wort nicht zur Karikatur macht. Eine Gesellschaft, die dem Menschen angemessen ist und ihn nicht der Struktur unterordnet. Das wird für uns alle viel Arbeit geben, auch viel Kleinarbeit, schlimmer als stricken." The speech is published at the website of the Deutsches Historisches Museum, http://www.dhm.de/ausstellungen/4november1989/hein.html.

${ }^{46}$ For an analysis of how the fall of the wall and the Wende has been frequently framed precisely as a spectacle, a party, a carnival, or a moment of collective effervescence, see Benjamin Robinson, "The End of an Event," After the Berlin Wall: Germany and Beyond, eds. Katharina Gerstenberger and Jana Evans Braziel, (Basingstoke, UK: Palgrave MacMillan, 2011), 179-182.

${ }^{47}$ Wolle, Die heile Welt der Diktatur, 53. Wolle describes how the seemingly endless queuing epitomized the peculiar slowness and quietness of late socialist society. Everyone was always waiting: "Man wartete - und zwar ständig und überall." Punning, East Germans converted the phrase "sozialistische Menschengesellschaft" invoked by Walter Ulbricht into the "sozialistische Wartegemeinschaft." See Wolle, Die heile Welt der Diktatur, 309. According to Joe Moran, the regime sought to label this shared experience of constant waiting into a "practical lesson in collectivity," each queue constituting a "Wartekollektiv." See Joe Moran, "November in Berlin: The End of the Everyday," History Workshop Journal 57 (2004): 220.

${ }^{48}$ Hein, Der fremde Freund, 175.

${ }^{49}$ Speaking at the GDR author congress in 1983, the journalist and writer Ingrid Feix's said: "Hier [in Hein's novella] wird eine Art zu leben vorgeführt, die Individualität sucht, aber die Möglichkeiten, die die sozialistische Gesellschaft für ihre Ausprägung bietet, nicht nutzt oder besser, nicht ausschöpft." Quoted in Masanetz, "Kommentar," 193.

${ }^{50}$ Claudia's life, one could even claim, fits the circumstances in the GDR of the early 1980s; what she says about her situation is consistent with basic scholarly accounts of the sociopolitical conditions. Under Erich Honecker, whose tenure as the general secretary of the SED stretched across the two final decades of the GDR, the party state focused on ensuring material equality and social security for the population, even as these policies would ultimately prove economically fatal for the country. See for instance Sigried Meuschel, Legitimation und Parteiherrschaft in der DDR (Frankfurt am Main: Suhrkamp, 1992), 222, 228. Honecker himself summarized his social policy simply: "The people need cheap bread, a dry flat, and a job." Quoted in Stephen Kotkin, Uncivil Society: 1989 and the Implosion of the Communist Establishment (New York: Random House, 2009), 48. Kotkin comments that the outlays for consumer and housing subsidies "leapt nearly sevenfold during the onset of his [Honecker's] rule and 1989." But the fact remains: in the seventies and eighties, people in the GDR did experience secure employment, a more or less egalitarian system of wages, and a broad range of subsidies for products and services deemed necessary, guaranteed by the political leadership. See Meuschel, Legitimation und Parteiherrschaft, 235. And if the GDR retained some of its appeal after its demise, it is much because of these socialist accomplishments, whether or not they were impressive by Western standards or economically sustainable over the long term. A GDR citizen was, Wolfgang Engler writes, "dem anderen sozial annähernd 
gleichgestellt, einer unter vielen, und zugleich ökonomisch unabhängig, einer für sich." Wolfgang Engler, Die Ostdeutschen. Kunde von einem verlorenen Land (Berlin: Aufbau, 1999), 211.

${ }^{51}$ Claudia is a free woman, insofar as she has left a stagnant marriage, terminated two pregnancies, and sees a male friend without any plan to remarry. Divorce, abortion, and short-term relationships are apparently no sources of stigma in Claudia's GDR, and the fact that she stands apart from various family and social ties does not come at a price of a volatile economic situation. As Katharina von Ankum argues, women's reproductive work was established as "one of the primary indicators of their ideological commitment to socialism" in the first decade of the GDR, but this "pronatalist orientation" was later toned down and abortion was declared free and legal in East Germany in 1972, a development partly prompted by international struggle for women's right to choose and visa-free travel to Poland, a neighboring country where abortions could be performed. See Katharina von Ankum, "Political Bodies: Women and Re/Production in the GDR," Women in German Yearbook 9 (1994): 129, 133.

52 The GDR was of course not a free market and, as the passage does indicate, access to supplies of goods and services could depend quite a bit on the attitude of those in charge of local production and distribution, such as a butcher, a hairdresser, and a tailor. As, Stefan Wolle writes, these figures belonged to the "Verwalter des Mangels" and could exercise a considerable power, or a "heimliche Herrschaft," over local distribution. At issue here, however, is how Claudia chooses to present herself, namely as a person in multiple convenient transactional relationships and little else. See Wolle, Die heile Welt der Diktatur, 297.

${ }^{53}$ Here I am indebted to Benjamin Robinson's argument summarized in note 31 : "From the liberal point of view, real socialism was a failed attempt at modernity with no ontological weight." See Robinson, The Skin of the System, 36-37.

${ }^{54}$ Christoph Hein: "Es entstand eine Gesellschaft, die wenig mit Sozialismus zu tun hatte." http://www.dhm.de/ausstellungen/4november1989/hein.html.

${ }^{55}$ Peter Brenner, Neue Deutsche Literaturgeschichte (Berlin: DeGruyter, 2011), 231.

${ }^{56}$ Lindner, "'Der fremde Freund,"” 1647.

${ }^{57}$ Focusing on two "prägende DDR-Erzählung[en]”-Uwe Tellkamp's Der Turm (2008) and Florian Henckel von Donnersmarck's Das Leben der Anderen (2006) Matthias Dell analyzes how the GDR made accessible for an audience socialized in the West is in fact frequently prepared and presented with this very audience in mind: "Der Film [Das Leben der Anderen] richtet die DDR genau so ein, dass sie anschlussfähig an den bürgerlichen Geschmack des Westens wird." What the (Western) public enjoys as an unvarnished depiction of the GDR has in fact been carefully organized for such enjoyment. Something of this effect inadvertently occurred with Hein's Der fremde Freund. By using a narrative pattern and discourses on emotions standard in the West, Hein leveled an internal critique at the GDR, with the consequence that West German critics could speak of a unified modern life world undivided by the Berlin Wall. See Matthias Dell, "Bring mir den Kopf von Gregor Gysi: Die DDR im Hubert-WinkelsWir," Merkur 67, no. 10-11 (November 2013): 1041. 